\section{John M. Alexander}

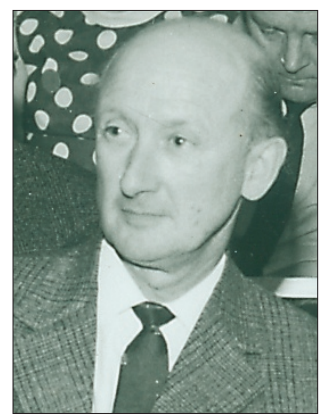

John (Jack) Alexander, the founder of the British Association of Orthodontists, died on 26 March 2004. Largely due to his initiative and drive, orthodontics outside the hospital service was accepted as a specialist discipline in this country with the consequent introduction of the specialist practitioner title.

The scion of a prominent Scottish family, Jack qualified at Guy's where he was a leading member of the Yacht and Ocean Racing Club. He had a good war in the navy, much of it at sea and ending up in the Far East. He also met Catherine, a WREN of outstanding beauty whose face adorned a thousand recruiting posters. She became his lifelong companion and a noted historian and art expert in her own right.

Jack returned to Guy's for formal orthodontic training under the famous Reggie Rix, who offered him a position in his West End private practice. After much heart searching Jack decided to follow instead his dream to become a country gentleman in the West Country. They bought a fairly derelict listed property at Langport, in the heart of Somerset. From there he visited five widely spaced general practices to provide much needed orthodontic services, acquiring particular repute for the recovery of
By sternly donning his monocle he could bring any group to order. Only
his closest friends knew that the lens
had usually fallen out.

palatally impacted canines. With Catherine's help he was able to restore the house and its wonderful gardens.

The formation of the British Association of Orthodontists (BA0) in 1965 was followed by many politically stormy years but Jack, as chairman and later first president, was always the charming face of the group. By sternly donning his monocle he could bring any meeting to order. Only his closest friends knew that the lens had usually fallen out.

After unification of all the national orthodontic groups in 1994 he was honoured with life membership of the newly created British Orthodontic Society. Jack was also a very active officer of the Somerset Local Dental Committee, the BDA and a sponsor of the Royal Bath and West Agricultural Show, which he and Catherine attended regularly in great style. They had truly become pillars of Somerset society. The impact of Jack's vision on the future of British orthodontics is immeasurable. He died aged 94.

H.L. Eirew

\section{Fred Allan}

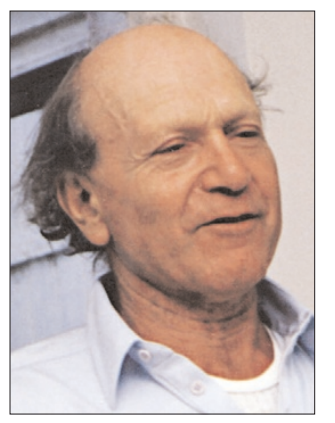

Fred Allan was born Fritz Fokschaner in Vienna, 1923. He escaped Austria after the Nazi occupation and eventually arrived in England as a refugee; as a 16-year-old boy he worked on a farm in Hampshire. He gained British nationality and changed his name to the more anglicised Frederick Allan when he joined the British army, choosing Allan so that he would get his pay earlier than anyone else. At that time the British army paid in alphabetical order! Fred saw Churchill drive by in Normandy and had previously seen Hitler parading through Vienna, so he was one of the few people to see both during the hostilities.

After the war, Fred initially trained as a dental technician. Although he came from a long line of Viennese dentists, he was surprised to find himself studying dentistry at Guy's Hospital. He married Joan in 1951... and in 1953 won a Fullbright scholarship to the Guggenheim Clinic in New York. After briefly returning to the UK to gain a diploma in orthodontics, he emigrated to Canada and gained a DDS at McGill university in Montreal. Missing England, Fred, Joan and their three young sons returned to England and Brighton in particular - where their fourth son was born.

Fred was a passionate believer in the NHS. He was one of the few dentists in Harley Street providing virtually exclusive NHS treatment. A rebel and an eccentric, he was always eager to try

\section{Predictably he was one of the first} swimmers on the nude beach in

\section{Brighton when it opened.}

out new techniques to improve efficiency in orthodontics. Many readers will undoubtedly remember his placard 'DOWN WITH ARCH WIRES' at a dental exhibition in Brighton. He was actively involved in the BDA in Brighton and London and was particularly proud to have become a member of the NHS Area Health Authority for Westminster and Kensington.

Fred's hobby was his farm in Ashdown Forest, bought cheaply because it had no vehicle access during the winter months. He built a road using discarded granite kerbstones, which most councils were replacing with concrete ones. It was not for nothing: Fred was known as the kerbstone millionaire. Having completed the road after many years, he built lakes. He was especially pleased to host one Area Health Authority meeting on the farm in the open air near the lakes. He swam frequently in the lakes, and was predictably one of the first swimmers on the nude beach in Brighton when it opened.

Eccentric, charming, determined and hard working, Fred brought a lot of pleasure to many people. He was much loved by all who were privileged to know him. He leaves his wife Joan, his brother Peter, stepbrother Walter and four sons. 